\title{
The Influence of Parenting Style on Adolescent Religious Commitment in Bandung, Indonesia
}

\author{
Bambang Samsul Arifin*, Silmi Fauziah Azzahra, Tahrir \\ Universitas Islam Negeri Sunan Gunung Djati \\ Bandung, Indonesia \\ *bambangsamsularifin@ uinsgd.ac.id
}

\begin{abstract}
This article aims to find out the influence of parenting style on the aspects of responsiveness and control of mothers and fathers toward religious commitment of private Islamic Senior High School students in Bandung, Indonesia. The method used in this study is a quantitative approach by the design of causality research to determine the effect of parenting variables on religious commitment. The participant consists of 131 students. The data analysis technique used is a simple linear regression analysis. The results showed that there was an influence of the mothers parenting on students' religious commitment with a significance value of 0,000 , which was smaller than the probability value of 0.05 . While the father's parenting significance value of 0.004 is smaller than the probability value of 0,000 , then there is a positive influence between parenting mothers and fathers toward the religious commitment of Manbaul Huda Islamic Senior High School students with an influence of $11.7 \%$ of parenting and $20,1 \%$ of fathers parenting.
\end{abstract}

Keywords—parenting style, religious commitment, adolescents

\section{INTRODUCTION}

The family is the first educational environment for children. They gain knowledge, values, morals, religion, and experiences that last a long time. Parents have an excellent opportunity to develop their children through parenting styles applied in the family, including religious education.

According to Nasution [1], supernatural powers, belief in supernatural powers as a determinant of human good and bad luck, emotional response from humans, and understanding of the holy. Therefore, children's obedience to children in implementing religious values and teachings requires parental guidance to exemplary religious commitment in their daily life.
The results of interviews with 15 students of Islamic Senior High School Manbaul Huda in Bandung, there were nine parents who ordered them to carry out religious teachings properly, such as prayer at the time of the five daily prayers. In addition, they received religious knowledge from their own parents for the first time. However, there were three students who said that it was their first time getting religious knowledge from the teacher at school. They often ask their peers and teachers personally about religious teachings. Eight other students said they rarely asked questions about worshiping their parents. Meanwhile, two students always practiced religious practices together with their parents, such as praying in congregation and discussing religion in depth. Some students who did not experience were told to carry out the Sunnah worship deeds.

The diversity of these teenage students' experiences in exploring and practicing their religion's values and teachings gave birth to a varied picture of religious commitment. This happens because of the diversity in parenting styles to their children in the family environment.

Based on this description, this research's main problem is, How does parenting style influence the religious commitment of adolescent students at Islamic Senior High School Manbaul Huda, Bandung, Indonesia?

\section{A. Literature Review}

The parenting style is described by Baumrind [2] with four types of parenting styles, namely authoritative, authoritarian, indulgent, and neglectful. According to Maccoby and Martin [3], these four parenting styles are obtained from the high-low categorization between control aspects and aspects of responsiveness. 
TABLE I. CHARACTERIZES OF PARENTING STYLES [4]

\begin{tabular}{|c|c|c|}
\hline & High Control & Low Control \\
\hline High & Authoritative: & Permissive/Indulgent: \\
\hline Responsiveness & $\begin{array}{l}\text { Firm and consistent control. } \\
\text { Monitor and provide } \\
\text { explicit standards for } \\
\text { children's behavior. } \\
\text { Give priority to the needs } \\
\text { and abilities of children. } \\
\text { Indicates the proper age of } \\
\text { maturity. } \\
\text { Encourage children to be } \\
\text { independent. } \\
\text { Attention. } \\
\text { Forgiveness. } \\
\text { Encouraging autonomy. } \\
\text { Offer a democratic climate. }\end{array}$ & $\begin{array}{l}\text { Often express } \\
\text { warmth and } \\
\text { affection. } \\
\text { Upholding the law } \\
\text { and authority. } \\
\text { High acceptance. } \\
\text { Take on the role of a } \\
\text { friend, not a parent. } \\
\text { Allowing children to } \\
\text { make their own } \\
\text { decisions. } \\
\text { Minimalizing } \\
\text { penalties. }\end{array}$ \\
\hline $\begin{array}{l}\text { Low } \\
\text { Responsiveness }\end{array}$ & $\begin{array}{l}\text { Authoritarian: } \\
\text { Authorized in control } \\
\text { practices. } \\
\text { Expect strict and } \\
\text { unquestionable adherence } \\
\text { to parental authority. } \\
\text { Not ready to accept the } \\
\text { individuality of the child. } \\
\text { Disobedience was handled } \\
\text { with strong discipline and } \\
\text { punishment. Negligence relative to } \\
\text { children's needs. }\end{array}$ & $\begin{array}{l}\text { Negligent/Neglectful: } \\
\text { Inattentive behavior. } \\
\text { Ignoring the child. } \\
\text { Little interaction with } \\
\text { children. }\end{array}$ \\
\hline
\end{tabular}

Religious commitment is the ability that a person has in establishing and internalizing religious values in daily life to be reflected in the form of behavior by the teachings of his religion [5]. This view contains five dimensions, namely belief, religious practice, experience, knowledge, and consequences. Meanwhile, in Islam's perspective, religious commitment means how a person defines religion as represented or reflected in how to understand and live religion. Then, the dimensions of religious commitment developed by Ancok [6] include belief, worship, practice, knowledge, and experience or appreciation.

\section{Methodology}

This study uses quantitative methods to examine the effect of parenting style variables on adolescent religious commitment variables using simple linear regression analysis. The research sample consisted of 131 teenage students starting from class X, XI, and XII majoring in Science and Social Sciences at Islamic Senior High School Manbaul Huda, Bandung City. Data were collected using a questionnaire in the form of a research instrument, namely the parenting style scale, to measure the subjects' parenting style and the Muslim Religious scale to measure the religious commitment of the subjects, which was arranged based on a Likert scale.

\section{RESUltS AND DISCUSSION}

In family life, two prominent figures play an essential role in developing children's potential, namely mother and father, both cognitive, social, moral, emotional, language, and religious development. Color in the interaction process carried out by parents to children is known as parenting style, likewise in adolescent religious commitment. Therefore, this study and discussion's results include the influence of parenting styles from mothers and fathers on adolescent religious commitment.

\section{A. The Influence of the Mother's Parenting Style on Religious Commitment}

TABLE II. REGRESSION ANALYSIS SUMMARY MODEL PARENTING STYLE AND ADOLESCENT RELIGIOUS COMMITMENT

\begin{tabular}{|l|c|c|c|c|}
\hline Model & $\mathbf{R}$ & $\begin{array}{c}\text { R } \\
\text { Suquare }\end{array}$ & $\begin{array}{c}\text { Adjusted R } \\
\text { Square }\end{array}$ & $\begin{array}{c}\text { Std. Error of the } \\
\text { Estimate }\end{array}$ \\
\hline 1 & $.342^{\circ}$ & .117 & .110 & 15.007 \\
\hline
\end{tabular}

Predictors: (Constant). Mother's parenting

Table 2 above shows that the $\mathrm{R}$ square value is 0.117 , which means that the influence of parenting style on adolescent religious commitment is $11.7 \%$. Simultaneously, the remaining $88.3 \%$ of religious commitment is influenced by other variables that are not examined. Based on this determination index, the mother's parenting style positively affects the religious commitment of adolescent students of Islamic Senior High School with a total influence of $11.7 \%$. This influence implies that the mother's increasing parenting style will affect the increasing commitment of the adolescent.

\section{B. The Influence of Father's Parenting style on Adolescent Religious Commitment}

TABLE III. REGRESSION ANALYSIS SUMMARY MODEL PARENTING AND ADOLESCENT RELIGIOUS COMMITMENT

\begin{tabular}{|l|c|l|l|l|}
\hline Model & R & $\begin{array}{c}\text { R } \\
\text { Suquare }\end{array}$ & $\begin{array}{c}\text { Adjusted R } \\
\text { Square }\end{array}$ & $\begin{array}{c}\text { Std. Error of the } \\
\text { Estimate }\end{array}$ \\
\hline 1 & $.448^{\circ}$ & .201 & .195 & 14.275 \\
\hline
\end{tabular}

Table 3 above shows that the value of $\mathrm{R}$ square is 0.201 , which means that the influence of the father's parenting style on adolescent religious commitment is $20.1 \%$, while the remaining $79.9 \%$ is influenced by other variables not examined. Based on this determination index, the father's parenting style appears to have a positive effect on the adolescent religious commitment by $20.1 \%$. This influence implies that the increasing parenting style by the father will affect the adolescent's commitment.

Then, the simple linear regression test results show that the mother's parenting style shows a constant number with a value of 100.816 and a regression coefficient value of 0.471 . Then the regression equation is $\mathrm{Y}=100.816+0.471 \mathrm{X}$; the significance value is 0.000 , which is smaller than the probability value of 0.05 . Because the regression coefficient has a positive value, the mother's parenting style positively affects adolescent religious commitment.

Meanwhile, the results of cross-tabulation of the control aspects of mothers with adolescent religious commitment and 
cross-tabulations of control aspects of fathers with high religious commitment with high maternal control parenting were more numerous than adolescent students. The latter had a high religious commitment with low maternal control parenting styles. Meanwhile, more students had a low religious commitment with high maternal control parenting styles than students who had a low religious commitment with high control parenting styles-likewise, the responsiveness aspect of the parenting styles of the father and mother.

Thus, it can be seen that the high parenting style in the aspects of control and responsiveness will form a high religious commitment. The results of this study indicate that all parents of teenage madrasah students, both from the mother's or the father's parenting style, apply the authoritative parenting style because the control and responsiveness aspects of the father and mother are the same.

The control aspect of this rearing style controls the behavior of parents towards their children in terms of supervision, efforts to discipline, and the formation of children's maturity [7]. These efforts are made to avoid the behavior of children who are not obedient to their parents. As for the responsiveness aspect, it is the response of warm parents, provides support, and acceptance of parents. In this case, the parents deliberately encourage their children to adjust [2]. These young students' high religious commitment is influenced by parents who are disciplined, provide supervision, warm responses, and support.

Parents who apply high discipline in obedience to religion, such as in carrying out worship so that their teenagers become accustomed to it. Warm responses from parents can be given to children when discussing religious values and teachings. Exemplary also has a role in providing examples of behavior that are relevant to the teachings of their religion. Discussions like this are part of religious commitment, namely the dimension of religious knowledge called the knowledge [5], that religious people have at least a minimum amount of knowledge about the basics of belief. In Islam, according to Ancok [6], this dimension concerns knowledge of the contents of the Koran, the principles of teachings that must be believed and implemented (the pillars of faith and the pillars of Islam), Islamic laws, and Islamic history. While carrying out the Sunnah practice is included in the aspect of religious practice, which includes aspects of worship or religious practice (sharia), which refers to several levels of Muslim obedience in carrying out religious activities.

\section{CONCLUSION}

Parenting style has a significant influence on the religious commitment of adolescent students at Islamic Senior High School Manbaul Huda, Bandung City. The role of parents in the family, both mother and father, is very important in guiding the direction of the religious development of their teenagers, so that they are able to live up to the values and religious teachings they adhere to properly in accordance with the provisions of their religion.

\section{REFERENCES}

[1] H. Nasution, Islam Rasional Gagasan dan Pemikiran, Bandung: Mizananggota IKAPI, 2000

[2] D. Baumrind,, "Current patterns of parental authority," Developmental psychology, vol. 4, 1971.

[3] E.E. Maccoby and J.A. Martin, Socialization in the context of the family: Parent-child interaction. Handbook of child psychology: formerly Carmichael's Manual of child psychology, 1983.

[4] K.A. Gafoor and A. Kurukkan, "Goal Orientation among Boys and Girls in Higher Secondary Schools of Kerala: How Parenting Styles Influence It?," Online Submission, 2014

[5] Ulfiah, Layanan Konseling untuk Menangani Perilaku Bullying di Sekolah/Madrasah, Bandung: Mpress, 2013.p.29.

[6] J. Ancok, Psikologi Islami. Yogyakarta: Pustaka Pelajar, 2008. p. 80-82

[7] B.S. Arifin, "Learning Model to Improve Teenagers' Self-Esteem and Motivation of Having Achievement," Jurnal Pendidikan Islam UIN Sunan Gunung Djati, vol. 3, no. 2, pp. 221-234, 2017. 